\title{
French-Medium Instruction in Anglophone Canadian Higher Education: The Plurilingual Complexity of Students and Their Instructors
}

\author{
Steve Marshall \\ Simon Fraser University \\ Danièle Moore \\ Simon Fraser University \\ Mariko Himeta \\ Daito Bunka University
}

\begin{abstract}
In this article, we analyze the plurilingualism of instructors and their students in a program taught through the medium of French at a multilingual, Anglophone university in Western Canada. We employ the lenses of plurilingualism and plurilingual competence in the analysis of data from a one-year qualitative study of plurilingualism across the disciplines at the university. We analyze interview data and students' writing samples, focusing on how French and other languages are used by instructors and students in classes, and on the professional dilemma that instructors face in such courses: are they disciplinary experts and/or French immersion teachers? In our discussion, we suggest that instructors' and students' classroom practices are the result of several factors, including institutional discourses around plurilingualism and the French language, personal beliefs and ideologies, experiences of mobility from France and Quebec to British Columbia (instructors), and normative practices previously experienced in French immersion schools (students).
\end{abstract}

\section{Résumé}

Dans cet article, nous analysons le plurilinguisme des instructeurs et de leurs étudiants dans un programme enseigné en français dans une université multilingue et anglophone de l'Ouest canadien. Nous utilisons les lentilles du plurilinguisme et de la compétence plurilingue dans l'analyse des données d'une étude qualitative d'un an sur le plurilinguisme à travers les disciplines à l'université. Nous analysons les données d'entretien et les échantillons d'écriture des élèves, en nous concentrant sur la manière dont le français et les autres langues sont utilisés par les instructeurs et les étudiants dans les classes, et sur le dilemme professionnel auquel les instructeurs sont confrontés dans ces cours: sont-ils des experts disciplinaires et / ou des professeurs d'immersion française? Dans notre discussion, nous suggérons que les pratiques de classe des enseignants et des étudiants sont le résultat de plusieurs facteurs, dont les discours institutionnels autour du plurilinguisme et de la langue française, les croyances et idéologies personnelles, les expériences de mobilité de la France et du Québec vers la Colombie-Britannique (pour les instructeurs), et les pratiques normatives déjà expérimentées dans les écoles d'immersion française (pour les élèves). 


\section{French-Medium Instruction in Anglophone Canadian Higher Education: The Plurilingual Complexity of Students and Their Instructors}

A large body of literature exists on the topic of English Medium Instruction (EMI) in global contexts, addressing the complex issues that come with teaching courses through English in higher education contexts where English is not the dominant language institutionally and/or locally (e.g., Doiz et al., 2012; Lin \& Lo, 2018). Many questions have emerged in the literature: What are the aims of such programs? Why do students take them? Who should teach them? How do students and their instructors communicate in such classes? And what is the ultimate goal of such courses - to teach students disciplinary knowledge or to provide a language immersion environment through which they can improve their linguistic competence or a combination of the two? There is a notable lack of related studies, however, that focus on languages other than English (Doiz et al., 2012), and in particular, studies on French-medium instruction (FMI) in minority contexts in Anglophone universities, to which the same questions apply.

A small number of Canadian universities have adopted FMI programs at the postsecondary level, which have been the subject of studies by Ambrosio et al. (2012), Knoerr and Weinberg (2013), Séror and Lamoureux (2014), and Séror and Weinberg (2016). Often referred to in terms of the Integration of Language and Content in Higher Education (ILCHE) in the literature, the theory and practice of these programs is not yet comprehensively documented. Similarly, the articulation of ICLHE and plurilingualism has only been the focus of a few studies (e.g., Borràs et al., 2012; Gajo et al., 2013; Wilkinson \& Walsh, 2015; Wilkinson \& Zegers, 2007).

It is with this gap in the literature in mind that we address the complexities surrounding an FMI program at a university in Metro Vancouver, Canada, in the findings of a one-year qualitative study. The French Language Program (FLP) at West Coast University $(\mathrm{WCU})^{1}$ is a program that attracts up to thirty students per year to study as a cohort, taking courses in public administration, history, and politics, taught in French. The main goals of the program are twofold: to offer a continuation pathway for selected students from British Columbia's French immersion schools who wish to continue their studies locally through the medium of French, and to produce "functionally bilingual" graduates (Action Plan for Official Languages, 2018), with expertise in political science and public administration, who will be employable in Canada's bilingual federal institutions.

West Coast University is a multicultural Anglophone institution, with approximately 20\% international students (most of whom speak English as an additional language), and an even larger number of plurilingual students who are either Canadian citizens or permanent residents of Canada. The university is located in Metro Vancouver, British Columbia, Canada. In the city with a population nearing 2.5 million, $41.8 \%$ of the population reported speaking a mother tongue other than the official languages of Canada, English and French, in the 2016 census. Among these languages, the most widely spoken were Chinese languages (Mandarin, Cantonese, and other Chinese languages) (45\%), Punjabi (17\%), Korean (6\%), Tagalog (5\%), and Farsi (4\%) (Statistics Canada, 2016a).

The majority of the students taking FLP courses at the university are graduates of British Columbia's French immersion secondary schools, ${ }^{2}$ with a smaller number of Francophone students from French-speaking families also enrolling in the FLP or taking selected courses while doing a different degree program through the medium of English. As 
such, the levels of competence in general and academic French of the FLP students can be quite varied. An important feature of the program is the third-year study abroad experience, which gives students the opportunity to gain international experience and improve their competence in French.

The two FLP instructor participants self-identified as Francophones, with French as their dominant language, and are experts in their disciplines. Instructors face a pedagogical dilemma that can affect their sense of identity as educators and their everyday classroom practices: is their role as experts in their fields to teach disciplinary content or to create a French immersion environment in which their students will flourish and improve their active and academic French language skills? Are these two goals complementary, incompatible, or somewhere in between? One area around which these questions and tensions revolve is the use of French language in classes: both students and instructors need to make choices about how and when French should be used, what kind of French should be used, and the extent to which languages other than French (namely, English and students' additional languages) should be encouraged or discouraged.

To look into these questions, we present selected data from a one-year study of plurilingualism across the disciplines at WCU in which we analyzed interviews with students and instructors, and students' writing samples. Our discussion in this article is framed around the following two research questions:

1. How are French and other languages used in class by instructors and their students?

2. How do instructors perceive and respond to the following dilemma about their role: are they disciplinary experts and/or French immersion teachers?

\section{Plurilingualism and plurilingual competence in higher education}

We employ the theoretical lenses of plurilingualism and plurilingual competence in our analysis, which allows us to place three factors at the centre of our analysis: language, in particular, the position of French as a medium of instruction in minority contexts and as a tool for learning and communication in classes; individuals' agency as socially situated actors, for example, the choices, actions, and decisions made by instructors and students in and around their learning; and the cultural perspectives that shape and are shaped by participants' practices in the FLP and in broader social contexts.

When we use the term plurilingualism to refer to sociolinguistic phenomena, it is with reference to plurilingual students' interactions in higher education contexts that are characterized by the use of multiple languages, which students may switch and mix creatively and for specific purposes, without necessarily being fully fluent in the languages involved (Marshall \& Moore, 2018). When exercising their plurilingual competence, individuals' use of their different repertoires should always be seen as context-dependent. In this regard, we recognize the plurilingual speakers in our study to be social agents (Council of Europe, 2001) or socially situated actors (Moore \& Gajo, 2009), whose choices and competence regarding language use change according to social, educational, and cultural trajectories, as well as perceptions of constraint and opportunity (Coste et al., 2009; Lüdi \& Py, 2009). In terms of agency (social practice) and the opportunities and constraints that students in the FLP negotiate in and around their studies, it is important to note that their ability to engender change recursively (Giddens, 1984) through their practices within the hegemonic structures of the university are limited. More likely, their 
lack of symbolic capital within the hierarchies of the institution would result in their structural conditioning (Archer, 2003; Bourdieu, 1994); in other words, they are more likely to reproduce the dominant discourses that they perceive and engage with regarding their plurilingualism, many of which represent multi-/plurilingualism through monolingualist lenses. That is not to say, however, that an agentive focus on individuals' practices is not useful in revealing the ways in which participants use language(s) and carry out their studies for strategic, communicative, and creative purposes, for which the impacts may be more "local" within the broader university.

As contextually situated actors, participants exercise their agency in ways that cannot be seen solely in terms of opportunity and freedom from constraint. Instructors' agency is not only affected by macro and micro institutional factors (in particular, what they may perceive as the conflicting dual objectives of the FLP), but also by their own personal/professional trajectories and experience of mobility from institutions in France and Québec to WCU in British Columbia. Students, on the other hand, are exercising their agency in transition from secondary to higher education (at least at the outset of their studies), and in the contexts of the language through which they are learning (French) being a minority language at both provincial and institutional levels. In this regard, students' practices in FLP classes may differ greatly from their language use with peers, friends, and family outside of the course, which may involve various combinations of English and other additional languages in their repertoires.

The position of language, in this case, French, in a multilingual, Anglophonedominant university, is central to our analysis. An important question to ask, therefore, is which French - academic French, informal French, French from France, Québec French, the French that students speak as a result of studying in British Columbia's French immersion schools (in a province where only 1.2 percent reported their mother tongue to be French in the 2016 census) (Statistics Canada, 2016b), or French mixed hybridly with other languages? Importantly, as a minority language of instruction and communication at WCU, French cannot be analyzed in isolation from its roles vis à vis English and the many additional languages that many WCU students speak in their daily lives. Moreover, French is the instructors' first and dominant language, the language of instruction of disciplinespecific course content; at the same time, French is also an objective in itself, as the course is conceptualized institutionally as a language learning continuation for French immersion high school graduates. In this way, the issues around French language can become problematic factors for instructors who may self-identify as experts in their disciplinary content, but who are teaching courses that require them to become, in many respects, language teachers, or at least language-aware teachers of their content.

A small number of studies have employed the theoretical lenses of plurilingualism and plurilingual competence to analyze students' practices in Canadian higher education, primarily in the contexts of courses taught in English. In Marshall and Moore's (2013, 2018) studies, the authors illustrated how languages such as Mandarin, Punjabi, and Korean are employed by plurilingual students, alongside English, as tools for learning at a higher education institution in Metro Vancouver. Marshall (2019) describes how instructors respond to students' plurilingual practices in different contexts across the disciplines, and argues that the success or not of plurilingualism-inspired teaching approaches depends on how perceptions of language, content, and context are configured differently across the disciplines. Similarly, Van Viegen and Zappa-Hollman (2020) compare plurilingual pedagogies at two institutions in western Canada. Recent studies from elsewhere in Canada 
include Chen's (2018) analysis of the relationship between academic language policy and plurilingual practices at a Canadian university and Galante's $(2018,2019)$ studies of students' responses to plurilingualism-inspired classroom activities in a Canadian English for academic purposes class. Other plurilingualism-focused studies in Canadian contexts have looked at thesis writing processes (Corcoran et al., 2018) and on critical plurilingual pedagogies in English for research publication processes (Englander \& Corcoran, 2019).

With a specific focus on students taking French medium instruction in Anglophone universities, Marshall and Laghzaoui (2012) analyzed the reasons why graduates of British Columbia's French immersion schools decided to continue their studies in French. Moore, et al. (2015) analyzed how plurilingual students taking a French medium program at a university in Metro Vancouver mixed French, English, and Chinese languages in and around their studies, while Moore et al. (2020) analyze the role of language portraits as tools through which students in a French cohort program at an Anglophone university in western Canada navigate their plurilingualism, mobility, and investment in learning through French.

\section{The study}

We present data from a one-year study of plurilingualism across the disciplines at WCU. Classes being taught in English and French were studied. For this specific article, the focal participants are two FLP instructors and 13 of their students. The data collection process began with the recruitment of the two FLP instructors of political science courses, who were contacted by email. The instructors allowed a member of the research team to attend eight hours of their classes as a non-participant observer, during which time the researcher took field notes and got to know the students and the focus of the teaching. The instructors also facilitated the recruitment of students for interviews by making time in their classes for students to read the study details for the project and sign consent forms to take part in interviews and share their written texts for analysis. All participants were informed that confidentiality would be guaranteed by changing the names of individuals, courses, faculties, and the university.

Authors 1 and 3 carried out interviews with individual students or pairs of students (depending on the participants' choice) in one of the researcher's offices or an open space in the students' department. During the semi-structured interviews, students answered a range of open questions about their language backgrounds, knowledge and attitudes around the French language, reasons for continuing to learn through the medium of French at the university, and their study practices and language use in their classes. Interviews were carried out mainly in French except for occasions when the researchers and students switched periodically to English.

The two instructors also agreed to be interviewed by the research team. Interviews took place with the three authors in the department where the instructors taught, and discussions focused on the following: instructors' linguistic and cultural backgrounds, their attitudes about teaching their disciplinary knowledge and expertise through the medium of French, language use in their classes, and how they responded pedagogically to the challenges they faced in their classes. For the purposes of finding answers to our research questions, we present excerpts from interviews with instructors and students, and samples of students' writing, specifically, notes that three student participants volunteered to share with the researchers. 
The following tables list the instructor and student participants whose data are presented - in their order of appearance below (Tables 1 and 2).

Table 1

Instructors

Name Course Origin

\begin{tabular}{lll}
\hline Jules & Poly 200 & France \\
\hline Dominique & Poly 190 & Québec
\end{tabular}

Table 2

Students and languages ( $f=$ family language)

Name Languages

\begin{tabular}{ll}
\hline Aleksa & Serbian (f), English, French \\
\hline Maya & Japanese (f), English, French, \\
\hline Ken & English (f), French \\
\hline Sasha & Serbian (f), English, French \\
\hline Naomi & Mandarin (f), English, French \\
\hline Payton & English (f), French \\
\hline Nadia & English (f), French \\
\hline Colette & Arabic (f), English, French \\
\hline Claudette & Cantonese (f), English, French \\
\hline Jing & French (f), English \\
\hline Roxanne & Mandarin (f), English, French \\
\hline Khloe & French (f), English \\
& Mandarin (f), English, French
\end{tabular}

\section{Data analysis}

We began by analyzing selected excerpts from the interviews with the two instructors in which they discuss aspects of their practice of relevance to the research questions. These excerpts were organized thematically around key themes of interest that relate to our research questions. We followed this with a thematically organized analysis of student participants' interviews and written texts. Students were invited to contribute examples of their written texts, which we present selectively in this article. We decided not to include the field notes taken during classroom observations as we did not find adequate links to the scope of the analysis in this article.

Interview excerpts are presented with no changes to grammar or vocabulary. A parallel translation in English follows each French interview excerpt. Where non-standard French is used by student participants, the English translations that follow may not reflect such usage. In interview excerpts, three periods ... indicates that text has been omitted and two periods .. indicates an abrupt stop. 


\section{Findings}

\section{The Instructors: Jules and Dominique}

In the following excerpts, the two instructors answer questions about how languages are used in their classes.

\section{How the Instructors use French in class}

In interviews, we began by asking Jules and Dominique to describe how they used French in interactions with students in class:

Jules : Je parle comme je vous parle maintenant ... j'encourage à poser des questions en français mais s'ils me posent une question en anglais je leur interdis pas du tout ... je vouvoie les étudiants, c'est important parce que ça crée une distance.

[I speak like I'm speaking to you now ... I encourage questions in French but if they ask a question in English, I don't forbid it at all ... I use the vous form with students, it's important because that creates a distance.]

Dominique : Utiliser les mots les plus simples possible ... j'essaie souvent de les encourager, à leur dire que je suis pas une figure d'autorité ... je parle un peu plus lentement, je fais vraiment très attention pour bien articuler ... ce qui est permis dans la classe c'est juste français.

[Use the simplest words possible ... I often try to encourage them, to say to them that I'm not an authority figure ... I speak a little slower, I make a real effort to speak clearly ... in the class, only French is permitted.]

Jules and Dominique provided markedly contrasting descriptions of classroom strategies in the FLP when it comes to the French language.

The first difference relates to the extent to which teachers in programs such as FLP should moderate their normal form of speech. Jules describes a French medium classroom in which he speaks French in the same way as he is speaking with the interviewers: Je parle comme je vous parle maintenant. In contrast, Dominique describes simplifying his French and speaking slowly and carefully: utiliser les mots les plus simple possible ... je parle un peu plus lentement, je fais vraiment très attention pour bien articuler.

Another notable contrasting point between the two participants is their view on the use of English in their classes. Jules tolerates the use of English for asking questions during classes: $s$ 'ils me posent une question en anglais je leur interdis pas du tout. In contrast, Dominique employs a French-only policy during classes: ce qui est permis dans la classe c'est juste français.

And perhaps somewhat paradoxically, in Dominique's French-only classroom, he attempts to break down student-teacher hierarchies: j'essaie souvent de les encourager à leur dire que je suis pas une figure d'autorité. Jules maintains a sense of distance and authority in his linguistically more tolerant classes: je vouvoie les étudiants, c'est important parce que ça crée une distance. Jules's patterns of vouvoiement (use of the formal second person pronoun vous) "to maintain distance" in interactions with his students differs from 
the practice of his colleague Dominique, who applies the norm of general tutoiement, which is more common in Quebecois French (use of the informal second person pronoun $t u$ ). Jules would appear to be breaking the normative usage (the use of $t u$ ) that students have been exposed to during French immersion studies in British Columbia. It could be argued that Jules's usage reflects his alignment with international expectations, and will serve his students well when they use their French in future international travels. In contrast, Dominique's practice, which is closer to the norms of Quebec French, may present students with a future language barrier in terms of politeness, as well as grammar they have not been exposed to. This brings us back to our central theme, that of instructors who self-identify as content experts, but whose classroom practices have implications for language teaching, and for the future practices of their students.

\section{How their students use languages in class}

Both Jules and Dominique concur, nonetheless, that the two languages used in their classes are primarily French and English:

Jules: Les étudiants entre eux parlent anglais ... je me rappelle pas avoir vu les étudiants parler autre chose que l'anglais ou le français. [The students speak English among themselves ... I don't recall seeing students speak anything other than English or French.]

Dominique: Par exemple si aujourd'hui j'explique la conception de la révolution des droits de Michael Ignatieff, et j'explique une idée un peu plus complexe, une de mes étudiantes Aleksa va se retourner vers Sasha et il va continuer, le petit chuchotement en anglais. [For example, if I'm explaining the concept of the revolution of rights of Michael Ignatieff, and I explain an idea that is a little more complex, one of my students Aleksa will turn toward Sasha and he's going to continue, whisper in English.]

The key features that are evident from the excerpts above are the use of French as the medium of instruction, as the main language of instructor-student interactions, and the common use of English in student-student interactions. In these French-dominant classrooms, however, there appears to be a notable absence of languages other than French and English, for example, the additional languages that many of the students speak at home or in other contexts at the university. The reasons for this may be, first, students' continuation of normative practices that they followed during their French immersion secondary education, during which such languages would generally be discouraged in classrooms (along with English) and, second, a lack of a critical number of speakers of any given "other" language to make it a linguistically viable code for students to use. In the case of the latter, the absence of the use of languages other than English in classes for general conversation and as tools for learning is a sharp contrast to other classes at the university that are taught in English, in which it is common for students to use languages such as Mandarin, Cantonese, Punjabi, Farsi, and Korean with classmates. 


\section{Disciplinary expert or language teacher?}

As stated above, an important factor to consider as underlying the instructors' practices and perceptions in the FLP is their self-identification: do they consider themselves to be disciplinary content experts whose primary role is to teach political science or do they accept that in a program such as FLP they also become teachers of French immersion in this rather unusual higher education context? Jules was quite clear that his main role was to teach political science:

Jules : Ma responsabilité à moi, c'est l'enseignement de la science politique plus que du français. [For me, my responsibility is to teach political science more than French.]

Accordingly, he did not see it as his role to make sure that students learn rules of language and attain high degrees of competence:

Jules : J'espère qu'ils acquièrent c'est un usage fonctionnel de la langue, pas nécessairement une maîtrise des règles. [I hope they'll acquire a functional use of the language, not necessarily a mastery of the rules.]

When asked about balancing the role of a political scientist and French immersion teacher, Dominique appeared to be more accepting of the dual role that teaching on FLP brought, describing his role in terms of hybridity:

Dominique: Un hybride, je suis un mélange des deux en fait. [A hybrid, I'm a mixture of both in fact]

For Dominique, the disciplinary content he teaches and the role of promoting immersion by teaching through the French medium were less separable than for Jules. To some degree, therefore, for Dominique, the language, in effect, merges with the content.

Jules and Dominique describe their classroom practices and their perceptions about their roles as teachers in terms of being socially situated actors (Moore \& Gajo, 2009) whose decisions and perceptions are shaped by the specific contexts of the FLP as well as their individual beliefs, which are reflections of their own experiences of mobility. The interactional strategies that they describe would not fully match our definition above of plurilingual students' interactions in higher education being characterized by the use of multiple languages that they switch between and mix freely and creatively. Instead, according to the two instructors, students reflexively self-regulate their language use, limiting their interactions to a traditionally diglossic separation of French and English, which they employ reflexively as they negotiate the localized social, educational, and cultural trajectories of the FLP (Coste et al., 2009; Lüdi \& Py, 2009). Of interest, therefore, is the extent to which the perspectives of the two FLP instructors above are shared by the students whom they teach. 


\section{The Students}

The student interviews took place around the same time as the interviews with the instructors. Student interviews were not used to develop themes that came up in interviews with the two instructors or vice versa, nor to confirm or disconfirm information. We do, nonetheless, attempt to make some connections between the two data sets where commonalities and differences emerge.

One such connection can be made between the instructors' perceptions about the dual purposes of the FLP (to learn disciplinary content, learn through French immersion, or a combination of the two) and the extent to which this duality is evident in students' reasons for taking the course.

\section{Students' reasons for taking the FLP}

A general discourse pervades institutionally at WCU that the main reason for students to take the FLP is to get a job in the federal government, which requires high degrees of French-English bilingualism. This view was stated by Dominique in the following excerpt - which has been included in the section on student participants' data to foreground their responses:

Dominique: La majorité m'ont dit qu'ils voulaient être fonctionnaire ... J'ai pas senti que c'était nécessairement dans l'amour de la langue de Molière ... [ou] que c'est assez normal au Canada de parler français puisque la bilinguisme fait partie d'une des valeurs du Canada. [Most have told me they want to be civil servants ... I haven't sensed that it was necessarily for the love of the language of Molière ... (or) that it's quite normal in Canada to speak French as bilingualism is a Canadian value.]

Dominique appeared to be disappointed while he explained his view that students take the course solely for the calculated instrumental purpose of getting a job in the federal government. In particular, he notes a lack of love for the language of Molière or of recognition among his students of bilingualism as an inherently Canadian value. Dominique's perception, however, was at odds with the ways that the student participants defined the position of French in their personal and professional lives. Four of the student participants included an idea akin to love for the French language and/or culture as a reason for continuing their higher education studies in the French medium, French as part of their identity, and their duty to protect and maintain French in the socio-historical-political context of Canada:

Aleksa: Je savais déjà que j'adore le français et j'aime étudier les langues donc c'était une décision assez facile à prendre. [I already knew that I love French and I love studying languages, so it was quite an easy decision to take.]

Maya: J'adore le français, oui je pense que c'est une de mes passions comme depuis mon enfance ... nous vivons ici en Canada, c'est un pays bilingue alors, c'est une partie de mon identité. [I love French, yes I think it's been one of my passions since 
childhood ... we live here in Canada, it's a bilingual country, it's part of my identity.]

Ken: C'était parce que j'ai vraiment aimé la culture français ... je pense que c'est notre pays est techniquement bilingue, c'est officiellement bilingue, et je voulais être bilingue parce que ça c'est, je pense que c'est un devoir canadien. [It was because I truly loved French culture ... I think our country is technically bilingual, it's officially bilingual, and I wanted to be bilingual because it's, I think it's a duty for Canadians.]

Sasha: C'était un de mes préféré cours en, à l'école secondaire et je voulais juste continuer ... c'est un pays bilingue donc les emplois au gouvernement, les fonctionnaires, j'espère d'employer le français après l'université. [It was one of my favourite courses at secondary school and I just wanted to continue ... it's a bilingual country so jobs in government, as civil servants, I hope to use my French after university.]

Aleksa was plain and simple: she took the course because she adores French. Maya and Ken gave responses that combined a passion or love for French with the other missing ingredient in Dominique's response above, bilingualism as a Canadian value: nous vivons ici en Canada, c'est un pays bilingue alors de ce côté c'est une partie de mon identité and je pense que c'est notre pays est techniquement bilingue, c'est officiellement bilingue, et je voulais être bilingue parce que ça c'est, je pense que c'est un devoir canadien. Equally, Sasha described French as a favourite subject in school, rather than something that he loved, to which he added the chance for future opportunities in federal government that would come with an FLP degree.

Love for the French language in bilingual Canada was less evident in the responses of the following student participants, who offered more practical, instrumental reasons for continuing their studies in French:

Naomi: Ils m'ont donné un bourse (rire) ... non c'est pas la seule raison ... je croyais que ça serait une bonne façon de trouver un emploi, c'est des considérations pratiques plutôt que passion. [They gave me a scholarship (laughs) ... no, that's not the only reason ... I thought it would be a good way to find a job, it's more practical considerations rather than passion.]

Payton: Avec le troisième année il y a une année d'échange, alors ça c'était une chose. [In the third year there is an exchange year, so that was something.]

Carol: Je le parlais déjà donc je voulais juste, je ne voulais pas le perdre, donc c'était bon de le continuer je pense ... moi je pense que je veux travailler avec le gouvernement, ou peut-être dans le secteur public donc c'est effectivement recommandé d'avoir le français. [I already spoke it so I just wanted to, I didn't want to lose it, so it would be good to carry on I thought ... I think I want to work for the government, or maybe in the public sector so it's recommended to have French.] 
In a matter of fact way, Naomi and Payton provide very practical reasons for taking the program: funding opportunities, finding a job, and a year as an exchange student. Neither refers to love or passion for the French language as a reason. As stated by Naomi: $c$ 'est des considérations pratiques plutôt que passion. Carol also offered a response that was practical in two ways. First, she describes the desire to continue to study in the French medium so as to build on the large investment she has made in the French language through studying French immersion, and second, the longer-term goal of finding a job in the federal government. Together, their responses reflect the reasons behind Dominique's lament at the students' instrumentality and lack of cultural-linguistic passion.

Rather surprisingly, only two of the student interviewees highlighted an interest in the academic discipline, political science, as a main reason for taking the FLP:

Nadia: Je voulais étudier les sciences politiques et en plus j'ai le français, c'est un bonus donc. [I wanted to study political science and I also have French, so it's a bonus.]

Colette: J'aime beaucoup apprendre les langues et puisque FLP on peut étudier aussi les sciences politiques. [I really like studying languages and with the FLP we can also study political science.]

Interestingly, while both Nadia and Colette state their interest in political science as a reason for taking the FLP, both tie that interest to language learning, mirroring the dual nature of the program in terms of its institutional identity and purpose.

One factor that is evident in the excerpts above is that a few students do describe choosing the FLP for a love of French language and culture; fewer, however, state that their reason for taking the program was a strong interest in political science. It may be a common feature of liberal arts-oriented Canadian institutions such as WCU that students may receive a rather general education in their first year or two of studies before declaring majors, and thus may not be strongly grounded in a specific discipline during their first two years of study. However, it does stand out as a notable feature that for a program with such a strong focus on political science, the subject itself was of minor importance; the associated goal of working in government seemed to be more evident.

\section{Students' perceptions of language use in class}

In the interviews with the instructors presented earlier, the norms of language use in class were described in the following general terms: the instructors used French as the medium of instruction and in interactions with the students, with the exception of occasional questions coming from students in English in Jules's class. The instructors also described the tendency for students to chat with each other in English in their classes. Notably absent was any mention of students' additional languages other than French or English playing any role in classroom interactions as they commonly do in many of the English-medium classes at WCU. The instructors' descriptions were largely mirrored in the responses of students as the following two excerpts illustrate: 
Claudette: Dans la classe c'est sûr ça va être en français et les gens répondent aux questions en français.

Interviewer: Et entre eux qu'est-ce qu'ils parlent?

Claudette: Je dirais majoritairement l'anglais mais des fois peut-être que leurs idées passent en français puis ils vont poser une question à l'autre puis ça va être en français, mais en majorité c'est en anglais parce que c'est naturel pour eux de parler en anglais

Interviewer: Et après la classe tu as dit que tout le monde changeait en fait.

Claudette: Oui tout le monde change.

[Claudette: In class it's definitely going to be French and people answer questions in French.

Interviewer: And what do they speak to each other?

Claudette: I would say mostly English but maybe if they are thinking in French they'll ask other students questions in French, but mostly it's in English because it's natural for them to speak English.

Interviewer: And after class, you said everyone changes.

Claudette: Yes, everyone changes.]

Nadia: Si j'ai une question à demander à Aleksa je vais la demander en français parce que je suis habituée à parler français pendant cette heure du cours, je pense en français pendant que le prof parle donc c'est plus facile, c'est plus naturel de la demander la question en français. [If I have a question I want to ask Aleksa I'll ask her in French because I'm used to speaking French during that hour of class, I think in French while the prof is speaking so it's easier, it's more natural to ask the question in French.]

Claudette's description of language use in class was a close reflection of the descriptions given by Jules and Dominique, their instructors: the class taught through French, students responding to questions in French, students speaking mainly in English to each other in class, and English used outside of class. Claudette and Nadia referred to the occasional use of French when students may be thinking in French: mais des fois peut-être que leurs idées passent en français puis ils vont poser une question à l'autre puis ça va être en français and je pense en français pendant que le prof parle donc c'est plus facile, c'est plus naturel de la demander la question en français.

The idea of a linguistically permissive classroom environment is evident in the following three participants' descriptions of classroom practices from Jing, Roxanne, and Carol:

Jing: [They] usually don't care as much about us just talking English just because it's not like learning about French as much it's about learning like history or science so they're a bit more like, yeah they let us speak English for these courses. [English excerpt]

Roxanne: Je pense qu'y a pas énormément de comme pression de comme avoir le parfait français au cours, je pense que c'est comme un environnement assez comme tolérant des différents niveaux. 
[I don't think there's an enormous amount of like pressure to like have perfect French in the course, I think it's like an environment that is pretty tolerant of different levels.]

Carol: Dominique parle à nous en anglais des fois et c'est un peu bizarre parce que j'ai jamais vu ça avec un professeur francophone, et des fois il parle à nous en anglais et je réponds à lui en français.

[Dominique speaks to us in English sometimes and it's a bit strange because I've never seen that with a Francophone professor, and sometimes he speaks to us in English and I reply in French.]

Participants have described a classroom environment in which the instructor does not enforce a strict French-only environment, in line with Jules's description of the FLP classes in which he teaches: where instructors let them speak English (Jing), an environment that is tolerant of different levels of French (Roxanne), and where students at times are addressed in English by a Francophone teacher and reply in French (Carol). Of interest is Jing's perception that the classroom is tolerant of the use of English because the purpose of the class is to learn the disciplinary content, not French language. It should be noted, nonetheless, that one participant, Khloe, described her FLP classes not in terms of linguistically tolerant spaces but as spaces of linguistic surveillance:

Khloe: It's far easier to express ourselves in English ... students will speak to each other in English unless the teacher is keeping a watch, looking out for any people who speak English when they're not supposed to. [English excerpt]

Within the contested tolerance of switching and mixing languages described above, the use of additional languages other than French or English is notably absent. The interviews revealed that only one participant, Sasha, described using his home language, Serbian, in classes with fellow Serbian speaker Aleksa:

Sasha: À la maison c'est seulement le serbe et avec mes amis c'est l'anglais, et aussi à l'école, maintenant à l'université, c'est le français principalement. Interviewer: Donc vous parlez [avec Aleksa] de temps en temps en serbe? Sasha: Euh quand on veut que personne d'autre nous com, comprend. [Sasha: At home, it's only Serbian and with my friends it's English, and also at school, university now, it's mainly French.

Interviewer: So you speak (with Aleksa) sometimes in Serbian?

Sasha: Um when we don't want other people to und, understand.]

Sasha describes breaking the French-English dominance of the classroom environment by using Serbian in the class. However, his use of his home language does not match closely the view of home languages being used as an asset for learning, a key concept within plurilingualism-inspired pedagogical approaches (Lau \& Van Viegen, 2020; Piccardo, 2013); in effect, Sasha explains that he uses the language with his classmate Aleksa when they do not want others to understand what they are saying. Two other students, Colette and Naomi, also mentioned communicating in a chosen language so that others would not 
understand, but in their case, the language was French, which they described using outside of FLP classes:

Colette: Parfois on parle en français

Naomi: Si on ne veut pas que les autres sachent sur quoi on parle on va parler.

Colette: Donc si ça fonctionne pas on parle chinois (rire) c'est ça

Naomi: On ne partage pas le même dialecte donc.

Colette: Comme moi je parle un dialecte très bizarre il y a (rire), elle parle le chinois standard.

[Colette: Sometimes we speak French.

Naomi: If we don't want others to know what we're going to say.

Colette: And if that doesn't work we speak Chinese (laughs) yeah

Naomi: We don't share the same dialect though.

Colette: Because I speak a weird dialect (laughs), and she speaks standard Chinese.]

While stating that she and Naomi use French at times outside of the cohort so that others will not understand, Colette then provides somewhat contradictory information about their use of Chinese. She first states that they will use Chinese instead of French for secret conversations if the context does not allow French to be used. Naomi then follows up by saying that she and Colette do not share the same dialect, to which Colette adds jokingly, she has a strange dialect. The contradiction is illustrative of the complexity of the repertoires of students such as Naomi and Colette: both speak different Chinese languages at home (Naomi-Mandarin, Colette-Cantonese); they appear to communicate in Mandarin at times for secret conversations when they feel that people may understand the alternative secret code, French; and they also explained that they do not speak Mandarin with other students in the cohort.

The fact that student interviewees described the same learning spaces quite differently is of interest. It shows that the interview data reflect individuals' perceptions of discursively constructed practices and norms in the FLP program, as well as in the broader university. They are also the result of knowledge that is co-constructed within the context of an interview between students, instructors, and researchers: co-constructed interViews (Kvale \& Brinkmann, 2009) through which interviewers and interviewees share, converse, joke, and interpret.

\section{Students' note-taking texts}

Three students provided samples of their note-taking texts for the researchers to analyze. Of interest to the researchers was the extent to which the above descriptions of oral language practices would be evident (or not) in the students' writing samples.

The following (Figures 1, 2 and 3) are three excerpts from Colette, who described her language use in and around her learning as follows above: sometimes uses French in class in addition to English, uses French occasionally outside of class with her friend Naomi if they do not what people to understand, and uses Chinese for the same purposes if French might be understood by others: 


\section{Figure 1}

Sample 1 of Colette's notes

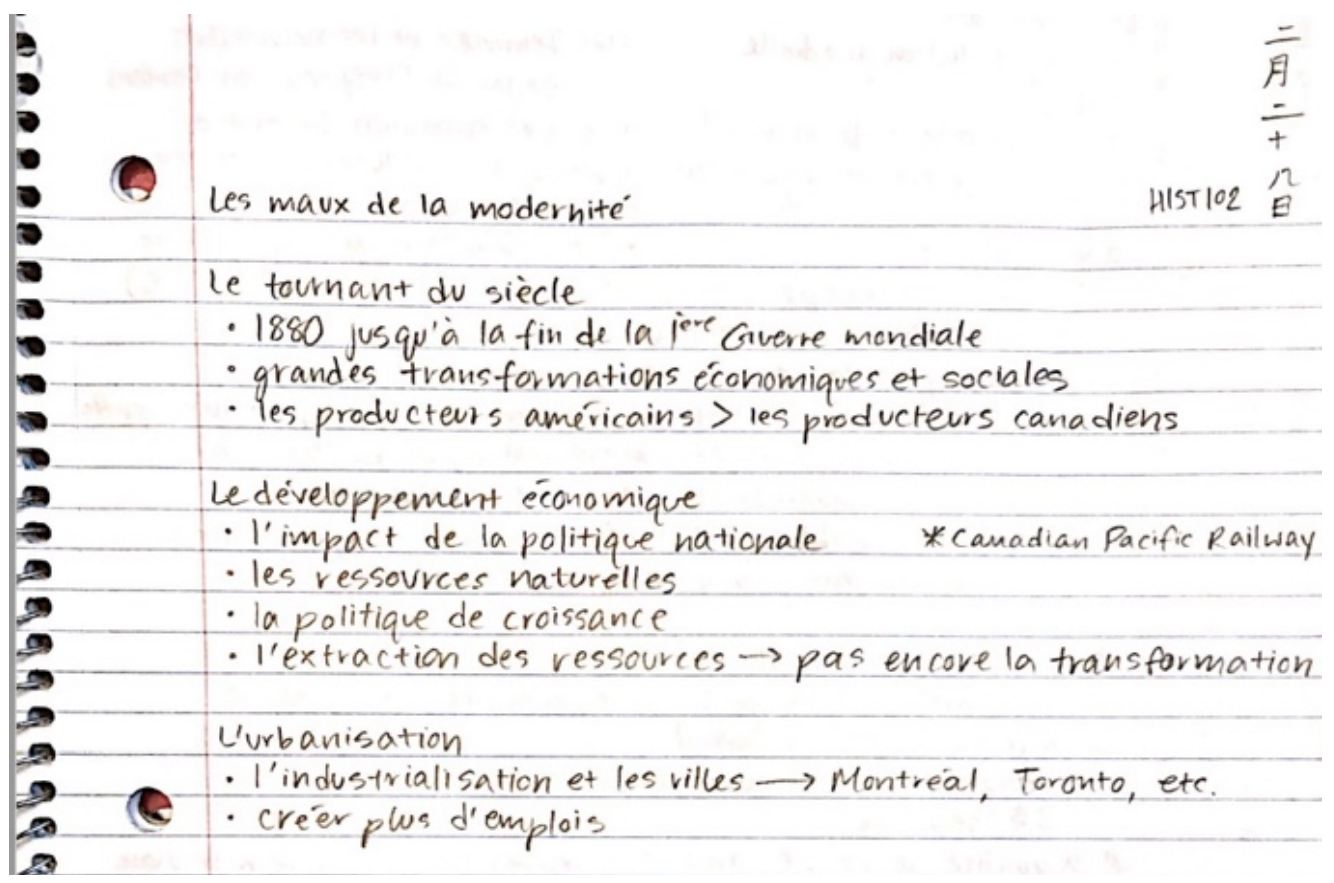

Figure 2

Sample 2 of Colette's notes

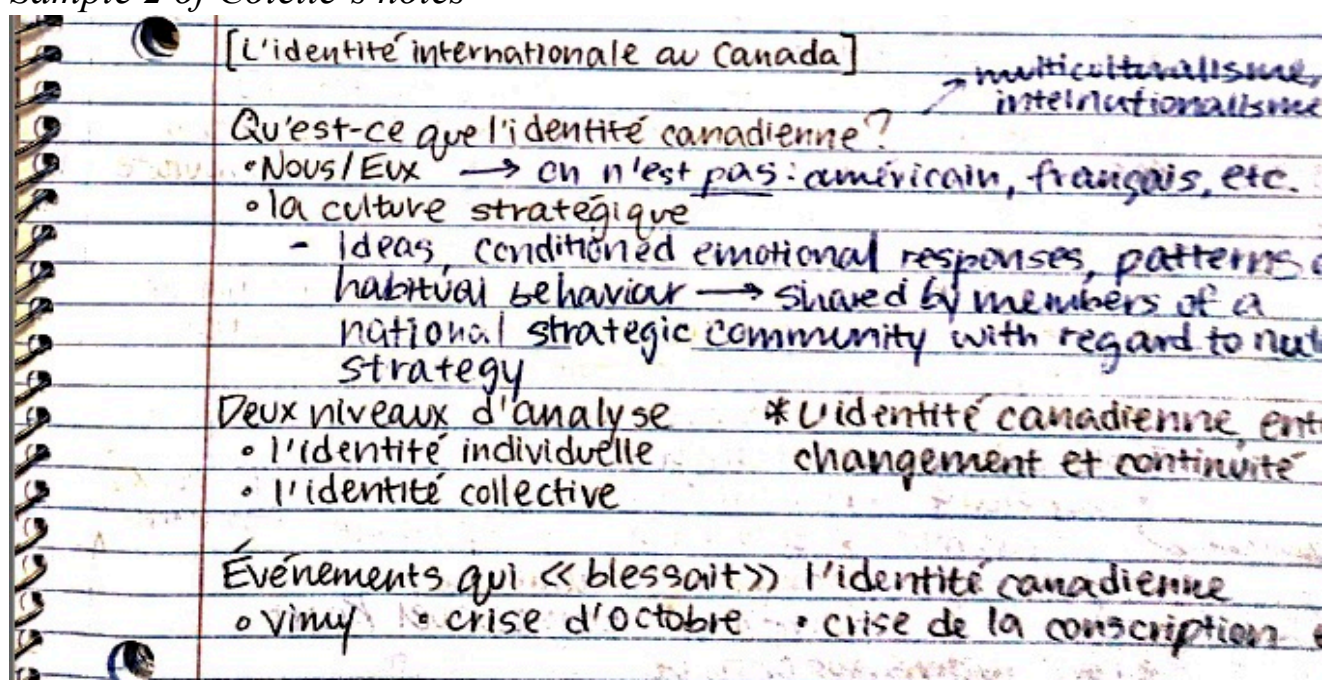




\section{Figure 3}

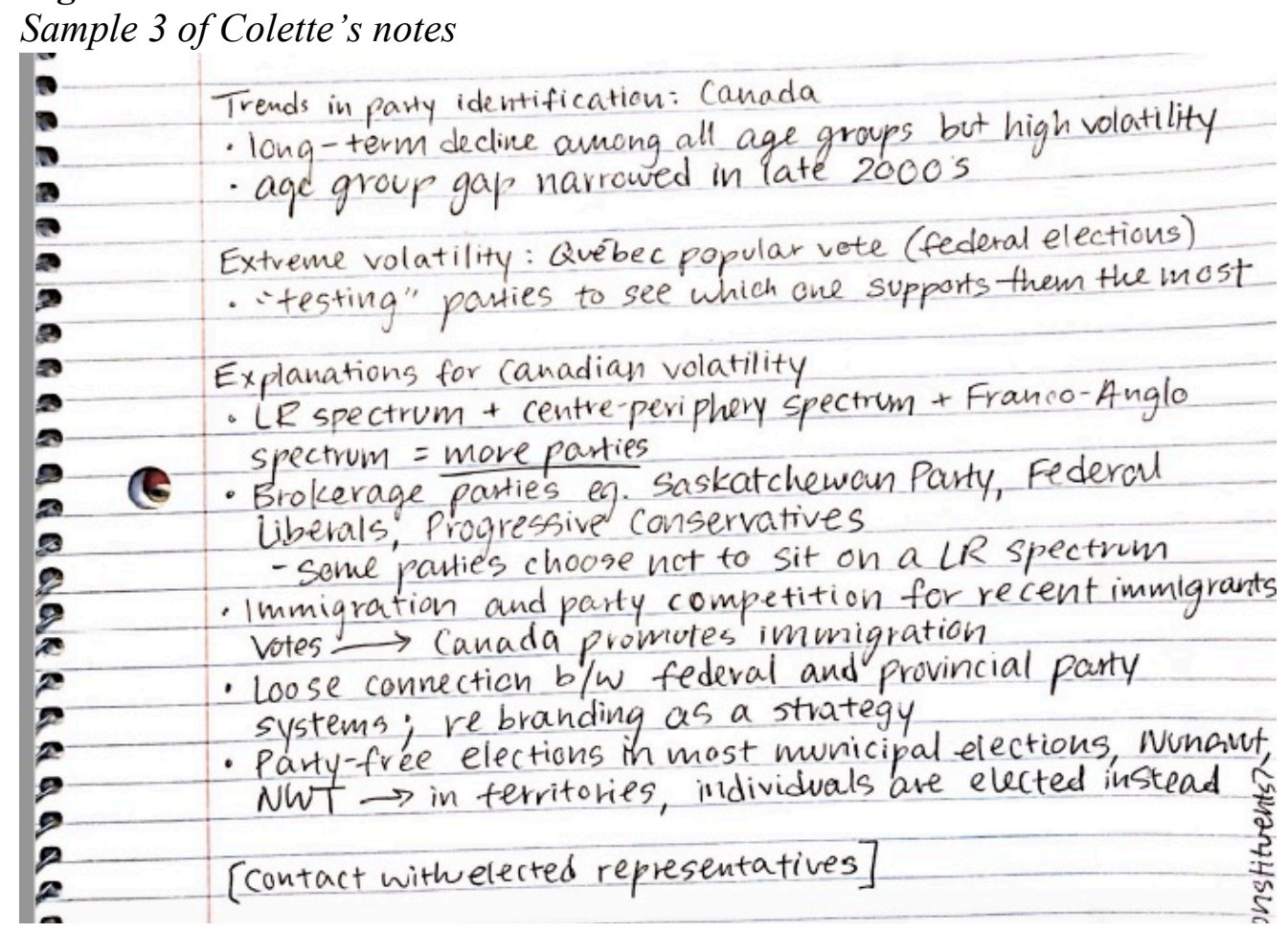

In sample 1 (Figure 1), Colette uses French exclusively to take notes in her history class. The only other language evident in the notes is the Japanese Kanji characters 二月二十八 $\theta$, which mean February 28th. Colette explained in her interview that when she got bored in classes, she would practise her written Japanese, which she was also studying. In sample 2 (Figure 2), Colette combines French and English - she begins her notes in French, switches to English, then continues again in French. The languages are alternated rather than mixed within sentences or in a hybrid form. Sample 3 (Figure 3) shows how Colette uses only English notes in an English-medium class that she took outside of the FLP. Together, the notes illustrate Colette's rich repertoire. Of note is the absence of her family language, Cantonese, in her notes. Colette explained that her home language was Cantonese but that she had limited written competence as she had forgotten most of what she learnt at Chinese school as a child, and that she was taught to write in Mandarin.

Another example of mixing languages while taking notes can be seen below (Figures 4 and 5) in the texts that were provided by Roxanne and Claudette. 


\section{Figure 4}

Sample of Roxanne's notes

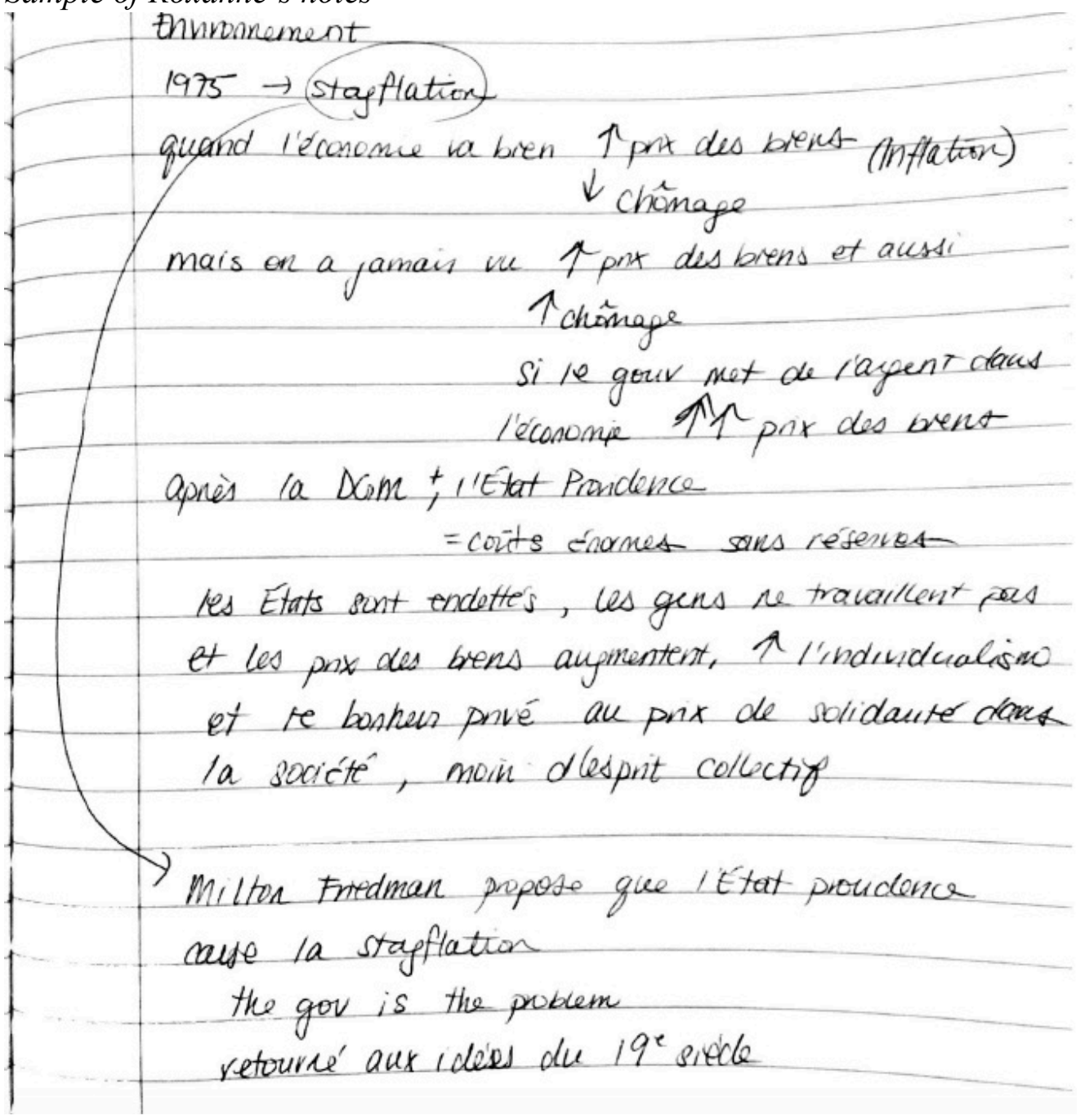

\section{Figure 5}

Sample of Claudette's notes

\section{hegatives}

= doesn't address all issues (Igniatieff)

$\rightarrow$ some cannot be explicitly stated (tovechildren)

- canprot let pights envalur u totalité dudiscours

$\rightarrow$ crise de la famille

- hack values: quality of life, love, loyalty and honor 
Roxanne alternates from French to English in her notes. Following an arrow down from the term stagflation Roxanne writes as follows: Milton Friedman propose que l'État ????? cause la stagflation, the gov in the problem, retourné aux idées du $19 X$ siècle. Claudette's sample differs from the other samples in the way that she combines French and English. In Claudette's sample, she starts the section of notes in English, explaining aspects of Ignatieff's view on rights. Mid-section, she performs an intra-sentential switch from English to French as follows: cannot let rights envahir la totalité du discours. She then continues in French in the space below before switching back to English.

Together, the writing samples provide a valuable parallel source of data that illustrates another layer of the multifaceted language environment and practices of the FLP classes. In the samples of notes above, English is used as a tool to engage with course content, not for non-academic purposes as described in interviews. In this sense, the students are able to exercise their plurilingual competence through their notes. The presence of languages other than French and English is limited, and not linked to academic engagement with course content. In this case, Colette's doodle of Japanese Kanji is due to her boredom perhaps, and to engagement with her learning a third language at university; moreover, it differs from the use of spoken Serbian that Sasha mentioned in that Japanese is not a family language of Colette.

\section{Conclusions and implications}

In the sections above, we have analyzed findings from a one-year study of plurilingualism across the disciplines at WCU, focusing on instructors and students taking the FLP, a French-medium program taught at a multilingual, multicultural, Anglophone university in Metro Vancouver, Canada. We described the dual content-language aims of the program and how instructors responded in different ways to the challenges of teaching around such dual program goals. In interviews, students described how they communicate in and outside of FLP classes, with some providing samples of their note-taking texts. We analyzed the data from the study through the theoretical lenses of plurilingualism and plurilingual competence, highlighting how different aspects of this theoretical analysis found representation in the data. Employing a qualitative methodological approach, we looked for answers to two research questions.

\section{How are French and Other Languages Used in Class by Instructors and their Students?}

Generally speaking, both instructors and students described a form of normative practice in their FLP classes: instructors used French to teach and in discussions with students; students used French in discussions with instructors; students used English mainly in their interactions with peers; occasionally, French was used in interactions between students, and English in interactions with instructors. Languages other than French and English were rarely used in classes. Outside of classes, English was the dominant code among the FLP students. We suggested that students' practices may have reflected students' transferring the normative practice they were exposed to in French immersion schools to FLP classes: norms that discouraged the use of languages other than French in class while English dominated outside of class. In addition, the use of languages other than 
French or English in classes would be less likely without a critical number of speakers of the same language to make it viable.

\section{How do Instructors Perceive and Respond to the Following Dilemma about Their Role: Are they Disciplinary Experts or French Immersion Teachers?}

While one instructor clearly self-identified as an expert in and teacher of political science and not a language teacher, another accepted that he was performing a hybrid role in the FLP, reflecting the dual aims of the program more closely. Each instructor responded differently to the challenges faced in such classes: creating distance from the students through using the vous form, trying to break down barriers and the instructor's position of authority, and requiring French only during class time. The strategies employed did not correspond directly or consistently to the language use of instructors. In other words, the French-only instructor did not describe attempts to maintain a distance between himself and students, while the linguistically-flexible instructor insisted on using the vous form to maintain a barrier with students.

What, then, did we learn by employing the analytical lenses of plurilingualism and plurilingual competence in our data analysis? At the outset, we framed the analytic analysis around three key factors - language, agency, and culture:

- Language, in particular, the position of French as a medium of instruction in minority contexts and as a tool for communication among participants;

- Individuals' agency as socially situated actors, for example, the choices, actions, and decisions made by instructors and students in and around their learning; and

- The cultural perspectives that shape and are shaped by participants' practices in the FLP program and in broader social contexts.

Many of the defining features of the literature on plurilingualism were evident in our data analysis. The plurilingual students we interviewed described the ability to use multiple languages in their daily lives, yet for most, the "other" language in FLP classes was English. One interviewee mentioned a tolerant classroom environment in which students could switch and mix languages; however, such practices were more evident in the notetaking samples that we also analyzed. In this regard, the student participants reflexively (Giddens, 1984) exercised their plurilingual competence as socially situated actors (Moore \& Gajo, 2009), depending on the constraints and opportunities they perceived and on the textual form of representation. Perhaps, note-taking was perceived as a less constrained space through which students could exercise their plurilingual competence.

We also revealed different Frenches in use: formal academic French (from France and Québec) for the purposes of maintaining distance, the varieties of French (with the notable presence of anglicisms) spoken by students in a province such as British Columbia with a very small Francophone population, as well as code alternation and code-mixing of French and English (described by students in interviews and evident in students' notetaking samples). We found no evidence of students mixing French with the other home languages they speak in and around the university.

The specific context of the FLP was a key determiner in the language choices students made. Students would use language differently with peers, friends, and family 
outside of the confines of the FLP. For example, the same student who uses no Mandarin in FLP classes, and who uses English in class conversations with fellow FLP students, may find herself using Mandarin for those very same purposes in other courses taught in English at the same university.

As stated by Shin and Sterzuk (2019), most Canadian campuses still function as sites of English (or French) monolingualism; moreover, despite Canada's official policy of bilingualism, only a handful of universities outside Quebec offer the possibility to study disciplines through French immersion programs While universities worldwide are increasingly switching to English to attract a wider student population and to prepare students for employment in an Anglophone-dominant business world, we have focused in this study on a French program offered at tertiary level in a minority context in an Anglophone province in Canada. Grin (2015) argues that the choice of language of instruction has an impact on the perceived value of the learning outcome. Our study points to the importance of learning more about the local practices of the integration of content and language, and content and plurilingualism, so as to facilitate and support knowledge construction in higher education (Gajo et al., 2013).

Although our study is small scale, our findings have implications for programs such as the FLP taught in minority contexts in Canadian universities and elsewhere. The first point to raise is the problems that might come with prioritizing the teaching of disciplinary content above creating a French-immersion-friendly classroom environment. For a course such as the FLP, the two are inseparable. Prioritizing disciplinary content over language becomes more problematic when we recognize that students taking the course placed an interest in political science low on the scale, the majority of the students were graduates of French immersion schools, and French was not their home language. We would suggest that a prioritized focus on content over language is better suited to classes made up of FLP students who have completed their year abroad in a Francophone country. In the first two years, balance is required.

We also found that instructors may have relied on oversimplified understandings of students' reasons for taking the program; while the general consensus may have been that students were primarily instrumental in their choice, in fact, students provided a broad range of reasons for continuing their studies in French. It could be argued that tapping into students' motivations and investments (Darvin \& Norton, 2016) in taking such courses through effective pedagogical tools would help to produce a teaching and learning environment of better mutual understanding between instructors and students. Moreover, it is not only the students who are instrumental in joining the FLP program. Professional benefits also come to instructors who come to British Columbia from France and Québec. In this regard, perceptions of students' instrumental goals for taking a program such as FLP could relate to self-reflection of one's own instrumental goals in teaching on a program.

Finally, an important aspect of the FLP is the year abroad opportunity in the third year, which one student alluded to in her explanation of why she signed up for the course. We would argue that this component is an essential part of any such course in Anglophone provinces of Canada. There is little doubt that a year in a Francophone environment (be it abroad or in Québec) provides students with an invaluable opportunity to improve their fluency and confidence in French (after many years of learning through French immersion environments). Equally, it allows students to broaden their cultural knowledge. These are essential skills to bring back to their final year of study as well as into their future careers. 
Correspondence should be addressed to Steve Marshall.

Email: sj_marshall@sfu.ca

\section{Notes}

${ }^{1}$ Pseudonyms are used for the names of people, places, and courses in this article.

${ }^{2}$ As of $2017-2018,9.5 \%$ of students in British Columbia had taken French immersion courses at some stage of their studies from kindergarten to Grade 12, the final year of secondary school (Canadian Parents for French, 2018).

\section{References}

Action Plan for Official Languages (2018). https://www.canada.ca/en/canadianheritage/services/official-languages-bilingualism/official-languages-actionplan.html

Ambrosio, L., Dansereau, M. C., \& Gobeil, M. (2012). L'immersion linguistique à l'Université d'Ottawa Une formule attrayante pour poursuivre l'apprentissage de la langue seconde. Synergies Europe, 7, 119-134.

Archer, M. S. (2003). Structure, Agency and the Internal Conversation. Cambridge University Press.

Borràs, E., Moore, E., Nussbaum, L. \& Patiño-Santos, A. (2012). Variétés de modes plurilingues dans des cours universitaires en L2. In Mondada, L. \& Nussbaum, L. (Eds.). Interactions cosmopolites : L'organisation de la participation plurilingue. Éditions Lambert Lucas.

Bourdieu, P. (1994). Language and Symbolic Power. Harvard University Press.

Canadian Parents for French (2018). Available at https://bc-yk.cpf.ca/researchadvocacy/enrolment-statistics/

Chen, L. (2018). The Enactment of Academic Language Policy in the International University: A Mixed-Methods Investigation. [Unpublished doctoral dissertation]. Western University, London, Canada.

Corcoran, J., Gagné, A., \& McIntosh, M. (2018). A conversation about "editing" plurilingual scholars' thesis writing. Canadian Journal for Studies in Discourse and Writing/Rédactologie, 28, 1-25.

Coste, D., Moore, D., \& Zarate, G. (2009). Plurilingual and pluricultural competence. Strasbourg: Council of Europe. Council for Cultural Co-operation. Education Committee.

Council of Europe. (2001). Common European Framework of Reference for Languages: Learning, Teaching, Assessment. Cambridge University Press.

Darvin, R., \& Norton, B. (2016). Investment and language learning in the $21 \mathrm{st}$ century. Langage et société, (3), 19-38.

Doiz, A., Lasagabaster, D., \& Sierra, J. M. (Eds.). (2012). English-medium instruction at universities: Global challenges. Bristol: Multilingual Matters.

Englander, K., \& Corcoran, J. N. (2019). English for Research Publication Purposes: Critical Plurilingual Pedagogies. Routledge.

Gajo L., Grobet, A., Serra, C., Steffen, G., Müller, G., \& Berthoud, A.-C. (2013). Plurilingualisms and knowledge construction in higher education. In Berthoud A.- 
C., F. Grin \& G. Lüdi (Eds.), Exploring the Dynamics of Multilingualism: The Dylan Project (pp. 279-298). John Benjamins.

Galante, A. (2018). Plurilingual or monolingual? A mixed methods study investigating plurilingual instruction in an EAP program at a Canadian university. [Unpublished doctoral dissertation]. University of Toronto, Toronto, Canada)

Galante, A. (2019). "The moment I realized I am plurilingual": Plurilingual tasks for creative representations in EAP at a Canadian university. Applied Linguistics Review, 33(2), 1747-7573.

Giddens, A. (1984). The constitution of society: Outline of the theory of structuration. University of California Press.

Grin, F. (2015). Managing languages in academia: Pointers from education economics and language economics. In G. Stickel and C. Robustelli (Eds.), Language Use in University Teaching and Research. Contributions to the 2014 EFNIL Annual Conference (pp. 99-118). Peter Lang.

Knoerr, H., \& Weinberg, A. (2013). L'immersion à l'Université d'Ottawa : une innovation héritée du passé. Les Cahiers de l'Acedle, 10(3), 15-35.

Kvale, S., \& Brinkmann, S. (2009). Interviews: Learning the craft of qualitative research interviewing. Sage.

Lau, S. M. C., \& Van Viegen, S. (2020). Plurilingual Pedagogies. Springer Nature.

Lin, A. M., \& Lo, Y. Y. (2018). The spread of English Medium Instruction programmes: Educational and research implications. In R. Barnard and Z. Hawim (Eds.) English Medium Instruction Programmes (pp. 87-103). Routledge.

Lüdi, G., \& Py, B. (2009). To be or not to be... a plurilingual speaker. International Journal of Multilingualism, 6(2),154-167.

Marshall, S. (2019). Understanding plurilingualism and developing pedagogy: teaching in linguistically diverse classes across the disciplines at a Canadian university. Language, Culture and Curriculum, 1-15.

Marshall, S., \& Laghzaoui, G. (2012). Langues, identités et francophonie chez des étudiants universitaires issus de l'immersion française à Vancouver, au Canada. Canadian Modern Language Review, 68(2), 216-233.

Marshall, S., \& Moore, D. (2013). 2B or not 2B plurilingual? Navigating languages literacies, and plurilingual competence in postsecondary education in Canada. TESOL Quarterly, 47(3), 472-499.

Marshall, S., \& Moore, D. (2018). Plurilingualism amid the panoply of lingualisms: Addressing critiques and misconceptions in education. International Journal of Multilingualism, 15(1),19-34.

Moore, D., \& Gajo, L. (2009). Introduction-French voices on plurilingualism and pluriculturalism: Theory, significance and perspectives. International Journal of Multilingualism, 6(2),137-153

Moore, D., Marshall, S., \& Himeta, M. (2020). Le portrait de langues pour «marcher» et s'approprier la mobilité? Feuilletés expérientiels d'étudiantes à l'université dans 1'ouest du Canada. Le Français dans le Monde, Recherches et Applications 68, 23 34.

Moore, D., Marshall, S. \& Zhu, Y. (2015). Plurilinguismes et identités à l'université. Les inter-maillages du français, du chinois et de l'anglais chez des étudiants de première année à Vancouver au Canada. In B. Bouvier-Laffitte \& Y. Loiseau. (Eds.). 
Polyphonies franco-chinoises. Mobilités, dynamiques identitaires et didactique. (pp. 81-100). l'Harmattan.

Piccardo, E. (2013). Plurilingualism and curriculum design: Toward a synergic vision. TESOL Quarterly, 47(3), 600-614.

Séror, J., \& Lamoureux, S. (2014). Regards croisés sur l'immersion au niveau universitaire : Perspectives étudiantes. Les dossiers des sciences de l'éducation, 32, 95-110.

Séror, J., \& Weinberg, A. (2016). Idéologie linguistique des acteurs du Régime d'immersion : le cas des professeurs de langues. In H. Knoerr, A. Weinberg \& A. Gohard (Eds.), L'immersion française à l'université : politiques et pédagogies (pp. 379-400). Les presses de l'Université d'Ottawa.

Shin, H., \& Sterzuk, A. (2019). Discourses, practices, and realities of multilingualism in higher education. TESL Canada Journal, 36(1), 147-159.

Statistics Canada. (2016a). Census Profile, 2016 Census. http://www12.statcan.gc.ca/census-recensement/2016/dp-p

Statistics Canada (2016b). https://www12.statcan.gc.ca/census-recensement/2016/dp$\mathrm{pd} / \mathrm{hlt}$-fst/lang/Table.cfm?Lang $=\mathrm{E} \& \mathrm{~T}=12 \& \mathrm{Geo}=59$

Van Viegen, S., \& Zappa-Hollman, S. (2020). Plurilingual pedagogies at the postsecondary level: possibilities for intentional engagement with students' diverse linguistic repertoires. Language, Culture and Curriculum, 33(2), 172-187.

Wilkinson, R. \& Walsh, M. L. (Eds.) (2015). Integrating content and language in higher education: From theory to practice. Peter Lang.

Wilkinson, R. \& Zegers, V. (Eds.) (2007). Integrating content and language: Meeting the challenges of a multilingual higher education. Maastricht University. 